\title{
EFFECT OF SELF-REGULATED LEARNING ON ACADEMIC ACHIEVEMENT OF PUANGRIMAGGALATUNG UNIVERSITY EDUCATIONAL ADMINISTRATION STUDY PROGRAM STUDENTS
}

Sumarni' , Nurhidayah², and Ahmad Suprianto ${ }^{3}$

Universitas Puangrimaggalatung

2,3Universitas Negeri Malang Malang, Indonesia

Email: 1sumarnifkip.ap@gmail.com

\begin{abstract}
This study specifically investigated the factors self-regulated learning on achievement academic students of the program study the administration of the education faculty of teacher training and science education. The design of this study applies a correlational design. The population study is a student at the Faculty of teacher and science education University Puangrimaggalatung program of study administration of the education workforce in 2017 until with student class of 2019 totaling 257 students with a total sample of 69 people. Based on the results of testing the data for the regression test, the results obtained significance $=0,000<0.05$. The hypotheses proposed are accepted that the influence of the variable self-regulation to the achievement of learning. The Hi accepted, which means no influence positively between self-regulation and achievement Akademik students of the Faculty of Teacher Training and Science Education University Puangrimaggalatung Program Study of Educational Administration Education. It demonstrated that the increasingly high self-regulation of the increasingly high achieving academic students.
\end{abstract}

Keywords: intellectual intelligence, self-regulated, and learning achievement

\section{INTRODUCTION}

Strengthening the quality of education should be a matter to be considered as they relate to the achievement of student academics. Students who have high potential have a greater chance of achieving the academic achievements expected at the level of education pursued. It means that if students use their potential optimally, and meet predetermined academic demands, the hope is to be able to achieve academic achievement optimally.

The student in adjusting to the academic field, it can be seen through academic achievement that is optimal values obtained via IP and CPI as well as timeliness in completing the study.
Academic achievement is interesting because it is related to students from various universities who have problems with their academic adjustments. Schneiders (1964) states that many students have difficulty adjusting to the academic situation, because of a basic conflict between what they want out of an education and what education is supposed to provide. It is especially likely to happen in a society like ours, in which pragmatic values dominate the thinking of many young people.

The success of the teaching and learning process is determined by how many factors, internal factors (within), and external factors (outside of themselves) students and teachers. Self Regulated 
Learning (SRL) interpreted in the Indonesian language "Independent Learning" is a factor in the self that is owned by students, both teachers and students in achieving their goals of improving learning and teaching.

According to Zimmerman (2000, in Schunk, 2001: 1), self-regulated learning is a systematic effort to direct thoughts, feelings, and actions to achieve their goals. The existence of efforts, do time management, set learning goals, use certain facilities or services to make learning activities more effective (helpseeking). For example, choosing certain learning models, choosing special teachers, or books that can help in the learning process and high self-efficacy (Zimmerman \& Kitsantas, 2005: 510-511).

Self Regulated Learning (SRL), as independent learning, should not be interpreted narrowly, but Self Regulated Learning (SRL) owned by someone can be used to develop themselves, to achieve success, so it should Owen by a student, student, teacher, lecturer or student the other. Understanding given by experts, selfregulated learning (SRL) is more directed at the personal life of each individual is looking at learning for himself. SRL is the state of the individual bear's responsibility and control for the acquisition of their knowledge.

Self Regulated Learning (SRLS) provides personal responsibility for the learners conducted, which includes selfcontrol and self-improvement learning efforts. An individual is said to be unable to adjust if sadness, disappointment or despair develops and affects his physiological and psychological functions. Individuals become unable to use their thoughts and attitudes well, so they cannot deal with pressures that arise satisfactorily. Vice versa, individuals are said to be successful in adjusting if they can achieve satisfaction in their efforts to meet their needs, overcome tension, free from various psychological disorders, frustration, and conflict.

Alsa (Arjanggi \& Suprihatin, 2010) states that cognitive, social learning theory has explained the ideal concept of selfregulation based learning. With a range of self-development mechanisms and selfmonitoring of thoughts, feelings, and behaviors to achieve goals that can help manage time and control self in its learning system, which in psychology manifested in the term self-regulated learning (SRL).

Santrock (2007) said that students who have SRL show the characteristics of regulating learning goals to develop knowledge and increase motivation. Also, they can control emotions, so they do not interfere with learning activities, periodically monitor the progress of learning targets, evaluate them, and make the necessary adaptations to support achievement. The researchers also found that there was a positive and strong correlation between SRL and academic achievement in students (Santrock, 2007). Moreover, SRL is a perfect strategy to 
improve learning and monitoring of achievements.

Pintrict \& Groot (1990) gives the term self-regulated learning with the term SRL. The concept of self-regulation was first put forward by Bandura in the setting of social learning theory. S elf-regulation in the learning process is not mental capabilities or an academic skills, but manage their learning process through setting and achieving goals by referring to metacognitive and peril I was active in independent learning ( Zimmerman, 2002).

A good adjustment will make students feel comfortable so that it can learn well. It confirmed that children's ability to adapt to the environment would make the child feel comfortable in the end. The child may have made achievements in school (Achenbach, 1991) da $n$ the research results also concluded that adaptability positively influences the various activities of $a$ person's good on and off-campus I Partosuwido, 1992).

Therefore, adjustment is also another factor that can play a role in supporting student academic achievement. Based on the description above, it can assume that learning based on Self Regulated Learning and adaptation are factors that play a role in the achievement of student academic achievement.

\section{METHODS}

The population study is a student at the Faculty of teacher and science education University Puangrimaggalatung program of study administration of the education workforce in 2017 Sampal with student class of 2019 totaling 257 students. Mechanical sampling in research determined by using the technique of snowball sampling. Snowball sampling is a technique of determining the sample that initially the number of small, then the sample asked to choose a friend of his to use as a sample ( Sugiyono, 2001). With several such samples in the research, this is as much as 69 people.

The method of collecting the data done by using the method of scale measurements of psychology in the form of a scale of self-regulation and study documentation. The scale used in research is the scale of self-regulation modified from the Motivated Strategies for Learning Questionnaire (MSLQ; Pintrich, Smith, Garcia and McKaechie, 1991). Reliability testing used to determine the consistency or reliability of the measurement results (Azwar, 2012). Reliability scale self-regulation to the achievement study of students calculated with Technik alpha Cronbach and obtained the results of the coefficient of reliability of 0626 , which means that the reliability scale is at the level of being. After the data is collected and arranged in tabular form, the data processed for analysis using SPSS for windows.

\section{RESULTS AND DISCUSSION}


In this study, there are two variables to be analyzed. The first variable is self-regulated learning. Self-regulated learning defined as a process that helps students organize their thoughts, behavior, and emotions to direct their learning experiences (Zumbrunn, Tadlock \& Roberts, 2011). The Self-regulated learning score obtained from the total score of the self- regulated learning questionnaire. The second variable is academic achievement. Winkel I Kurniawati \&
Leonardi, 2013) defines academic achievement as a display of one's learning outcomes, which is the result of an assessment in the field of knowledge, skills, and attitudes as learning outcomes expressed in the form of values. Academic achievement scores obtained from the first-semester student achievement index scores.

The results of the measurement of self-regulation variables from research subjects shown in the following table

Table 1

Measurement Result of Self-Regulation Variable

\begin{tabular}{|c|c|c|c|c|c|c|c|}
\hline Range & Category & Frequency & $\begin{array}{c}\text { Percent } \\
(\%)\end{array}$ & $\begin{array}{c}\text { The } \\
\text { mean }\end{array}$ & SD & Mim & Max \\
\hline $74.5 \leq x<92$ & Very high & 4 & 5.79 & & & & \\
\hline $57.5 \leq x<74.5$ & High & 57 & 82.60 & 63.30 & 6.11 & 43 & 76 \\
\hline $40.25 \leq x<57.5$ & Low & 7 & 10,14 & & & & \\
\hline $23 \leq x<40.25$ & Very low & 1 & 1.44 & & & & \\
\hline
\end{tabular}

Based on the results of the normality test, values obtained Kolmogorov Smirnov. The significance of the two-tailed is higher than 0.05 (0.103) 0.05). It shows that the self-regulation data normally distributed. Based on the linearity test results, it knew that self-regulation is positively linear correlated with academic achievement. The data linearly correlated with $\mathrm{F}$ of 0.106 with a significance of .732 ( $p>0.05)$. Then it can be assumed that in the independent variable self-regulation, there is no multicollinearity problem.

Linear regression analysis. Used to see whether there is an effect of selfregulation variable on student achievement, which realized in the form of GPA. Based on the results of the test using
SPSS obtained equation $Y=a+b X Y=3$. $534+0.008 \times$ From the equation above shows that if not, there are variables GPA, then significant self-regulation is 3.534. At the same time, the value of the coefficient of the regression variable $\mathrm{CPI}$ for 0008 meant that any addition of one unit variable GPA would increase the change in behavior by 3. 534 .

Hypothesis testing. Carried out a way of notice significance, the stipulation if the significance of $>0.05$, then $\mathrm{HO}$ is accepted, but when the significance of $<0.05$, then $\mathrm{HO}$ is rejected, and $\mathrm{Hl}$ accepted. From the table at the bottom, it knew that the magnitude of significance $=$ $0.000<0.05$. The hypotheses proposed accepted that there is the influence of the variable self-regulation on the 
achievement of learning. The results of testing can see in the table below this.

Table 2 Regression Test

\begin{tabular}{|c|c|c|c|c|c|}
\hline Model & \multicolumn{2}{|c|}{$\begin{array}{c}\text { Unstandardized } \\
\text { Coefficients }\end{array}$} & $\begin{array}{c}\text { Standardized } \\
\text { Coefficients }\end{array}$ & & Sig. \\
\hline & B & Std. Error & Beta & & \\
\hline 1 Constant & 3,534 &, 462 &,- 036 & 6,384 & 000 \\
\cline { 1 - 3 } SR &, 008 &, 005 & & 6,425 & 000 \\
\hline
\end{tabular}

to the achievement of learning that is

Based on the results of testing the data for the regression test, the results obtained significance $=0,000<0.05$. The hypotheses proposed are accepted: the influence of the variable self-regulation to the achievement of learning the Hi accepted. It means no influence positively between self-regulation and achievement

Akademik students of the Faculty of Teacher Training and Science Education University Puangrimaggalatung Program Study of Educational Administration Education. It demonstrated that the increasingly high self-regulation of the increasingly high achieving academic students.

The results of her research bags with the findings of the experts who stated that good self-regulation, then people will be able to perform academic activities much better than people with selfregulation that bad (in McCoach, Ruban, McGuire \& Reis, 2003). Findings others also provide evidence of empirical ecological apply to the importance of considering both components of learning motivation and self-regulated in our model the performance of academic classes. It can conclude that self-regulation gives effect good for the participant students. It can say that a student who has self-regulation high, the achievement of learning will be much better than the students who have self-regulation low.

With the self-regulation that's making well, then affect the Presta s I academic students. Sensitize students to the development of self and selfmonitoring on the thoughts, feelings, and behaviors to achieve a goal associated with academic objectives or goals socioemotional (Santrock, 2007). Selfregulated learning is an attitude that maintains self-quality and tenacity as opposed to academic procrastination which often delays work, delays in working on assignments, incompatible schedules with performance and performs more enjoyable activities (Ferrari, et al., 1995)

Further research in tian conducted and concluded that the way parents in guiding their children in solving a problem a right to determine how the child is learning to use self-regulated learning (Ajisuksmo 1996). Individual differences; the insignificant correlation between self-regulated learning and student academic achievement may also 
be due to the many factors that affect the academic achievement scores. Not only determined by the ability of self-regulated learning.

Factors that affect academic achievement students (Sitepu, 2014 ), namely: 1. External factors are factors that come from outside the individual, which include: non-social factors, such as the state of air, air temperature, weather, time, place, tools used for learning. These non-social factors can directly affect someone's psychological impact on the achievement results that will obtain on students. While social factors are human factors (fellow human beings), both humans exist (present) and are not directly present 2. Internal factors originate from within the individual, including physiological factors, namely the physical state behind the learning activities. When a healthy physical condition will have a positive influence on a person's learning process so that the learning process will provide optimal results. While psychological factors include interests, talents, intelligence, personality, and motivation of students.

\section{CONCLUSION}

Based on the results of data analysis and discussion previously described. Hypothesis testing was done by looking at the significance $=0,000<0.05$. Thus the hypothesis is accepted that there are self-regulation variables that influence the learning achievement, which means there are influences that are positive between self-regulation and achievement of students of the Faculty of Teacher Training and Science Education University Puangrimaggalatung Program Study Adiministrasi Education. It shows that the higher the self-regulation, the higher the academic achievement.

\section{REFERENCES}

Achenbach, T., 1991. Manual for Youth Self-Report and 1991 Profile. Burlington: University of Vermont.

Ajisuksmo, CRP, 1996. Self Regulated Learning in Indonesia Higher Education. Jakarta: Atmajaya Research Center

Anggani, DM, 2010. The Relationship Between Self-Regulated Learning and Academic Achievement. Thesis: Psychology Faculty, Soegijapranata Catholic University, Semarang

Arjanggi, R. \& Suprihatin, T., 2010. Peer tutor learning methods improve learning outcomes based on selfregulation. Makara, Social Humanities, Vol. 14, No. 2, December 2010: 91-97.

Azwar, S (2000). Reliability and validity. Yogyakarta: Student Library.

Ferrari, Joseph R., Johnson, J. \& McCown, W. 1995. Procrastination and Task Avoidance. New York, USA: Plenum $P$

Kurniawati, R. \& Leonardi, T. (2013). The relationship between metacognition and academic achievement in Airlangga university psychology faculty students who actively organize in faculty level student organizations. Journal of Educational Psychology and Development. Vol 2, No. 1, pp. 17-18.

McCoach, BD, Ruban, ML, McGuire, MJ, \& Reis, MS (2003). The differential impact of academic selfregulatory methods on academic achievement among university students with and without learning 
disabilities. Journal of Learning

Disabilities, 36 (3), 270-286.

Partosuwido, SR, 1992. Student Self Adjustment about Self Concept, Center of Control, and Higher Education Status. Thesis (Not Published). Yogyakarta: Faculty of Psychology, Gadjah Mada University.

Pintrich, PR, EV de Groot. (1990). Motivational and self-regulated component of the classroom. Journal of Educational Psychology, $82,1,33-40$

Santrock, JW JW 2007. Live Span Development, Lifespan Development. Fifth Edition Volume 2. (translation of Chusaeri and Darmanik). Jakarta: Erlangga.

Schneiders. (1964). Personal Adjustment and Mental Health. New York: Holt, Rinehart, and Winston

Sugiyono, 2001 . Statistics for research . Bandung: CV Alvabeta.

Zimmerman, Barry. J . \& Risembereg, Rafael. 2007. Self Regulatory Dimensions of Academic Learning and Motivation. New York: Academic Press, Inc. Zimmerman, Zimmerman, 2002 Barry. J . \& Kitsantas, Anastasia. The Hidden Dimension of Personal Competence: Self Regulated Learning and Practice. In Elliot, Andrew J. \& Dweck, Carol S. 2005. Handbook of Competence and Motivation. New York: The Guilford Press. 